\title{
Functional foods, conventional treatment and bioactive compounds, and assistance in the management of inflammatory bowel disease
}

\author{
Lluvia Castaneda ${ }^{1}$, Bryan Singharaj ${ }^{2}$, and Danik Martirosyan ${ }^{3}$ \\ ${ }^{1}$ University of California, Santa Barbara, CA; ${ }^{2}$ Stanford University, Stanford, CA, USA; \\ ${ }^{3}$ Functional Food Institute, 4659 Texas Street, Unit 15, San Diego, CA 92116, USA
}

Corresponding author: Danik M. Martirosyan, PhD, Functional Food Institute, 4659 Texas St., Unit 15, San Diego, CA 92116, USA

Submission Date: November $11^{\text {th }}$, 2017, Acceptance Date: January $27^{\text {th }}$, 2017, Publication Date: August $31^{\text {st }}, 2018$

Citation: Singharaj B., Castaneda L., Riscuta G., D. Martirosyan, Functional foods, conventional treatment and bioactive compounds, assist in management of inflammatory bowel disease. Bioactive Compounds in Health and Disease 2018; 1(4); 40-59. DOI: https://doi.org./ 10.31989/bchd.v1i4.409

\begin{abstract}
Ulcerative colitis, illeitis, and colonic Crohn's disease are the most common inflammatory bowel diseases (IBS). The etiology of this group of diseases is complex and has still not been entirely elucidated. Nonetheless, IBS is at least partially attributed to microbiota imbalance, which leads to an abnormal immune response. Due to the gravity of this condition, its impact on the quality of life, and increasing incidence, many investigations have been conducted with conventional and alternative treatments. While conventional medicine is partially beneficial, it cannot completely control the disease. There are frequent relapses and symptomatology often persists. Accordingly, specific diets, functional foods, and herbal medicine may offer a solution to restore intestinal microbiota and gut health, in addition to improving symptomatology. This review will focus on the diagnosis and management of IBD with respect to functional foods, bioactive compounds, and the potential of conventional treatment.
\end{abstract}

Keywords: IBD, Crohn's disease, ulcerative colitis, inflammation, treatment, microbiota, functional foods, bioactive compounds, bioactive ingredients, remission, effect.

\section{INTRODUCTION}

According to the Centers for Disease Control and Prevention, about 1-1.3 million people in the United States currently suffer from intestinal bowel disease (IBD) [1]. IBD includes both Crohn's Disease (CD) and ulcerative colitis (UC). In IBD, the gut microbiota interferes with normal intestinal functions, becoming both the cause and recipient of abnormalities of intestinal motility, 
sensitivity, and neuroimmune signaling. This results in alterations of mucosal barrier, pattern recognition receptors expression, and dysfunctions of hypothalamus-pituitary-adrenal axis [2].

The community of microorganisms residing in the human gastrointestinal (GI) tract is known as GI microbiota, and is composed of about one thousand commensals and/or symbiotic microbial species. This community includes viruses (including bacteriophages), bacteria, archaea, and unicellular eukaryotes comprised of fungi and other non-bacterial and non-archaeal microbial species [3]. Microbiota can alter the health or nutritional status of the host in order to fight against pathogens, a process that is a potential contributing factor to IBD [4]. Gut microbiota participate in host protection from pathogenic microbes, regulate metabolic pathways, and drive the maturation of the host immune system [5].

However, changes in the microbiota can also be associated with and are a feature of various diseases. Pathogens in the gut vary among animal species. In a study that compared different hosts (e.g. cattle, chimpanzees, and humans) in the same environment, similarities were observed between gut pathogens in humans and other species. These similarities may be the result of phylogenetic similarities in gut flora. Investigators additionally discovered that varieties of bacterial species may also be the result of dietary differences [6]. In humans, the intestinal tract contains a range of about 100 bacterial colonies, with the colon containing the majority of these bacterial colonies (about $10^{12}$ ) [7]. The microbiome is located in the intestinal tract and defined as "...the collection of organisms and their genomes inhabiting locations both in and on humans."

The "collection of organisms" consists of anaerobic or aerobic bacteria (e.g. Bacteroidetes, Firmicutes, Actinobacteria, and Proteobacteria) [8]. Microbial implantation does not occur until birth. If delivery is vaginal, the infant will experience bacterial colonization when it contacts maternal fecal and vaginal microbiota [9].

If delivery is conducted via cesarean section, the infant will receive microbiota from the surrounding environment [9-10]. The microbiome, with its distribution and richness of microbiota can be influenced by either the environment or diet; this includes the expression of different immune responses within the niche habitats in the proximal and distal sections of the intestine [4]. Varying diets will also affect microbiome diversity. For example, the differences between a high protein, high fat "western" diet and a low fat "non-western" diet can alter the abundance of microbiota [11-12]. Studies have demonstrated how higher fat diets increased Firmicutes, Proteobacteria, and Clostridium while reducing the number of Bacteroidetes and Bifidobacterium [13-17].

When the microbiota equilibrium is disrupted, the host can develop an imbalance [18] called dysbiosis. Alteration of the host environment into a state of dysbiosis can affect mental health and may lead to depression [19].

A new term, "psychobiotic," has been established and defined as "a living organism, that when ingested in adequate amounts, produces health benefits in patients suffering from psychiatric illnesses" [20]. Brain-gut interactions have been identified which may be modulated by gut microbiota via immunological, neuroendocrine, and neural mechanisms that can induce systemic inflammation [21]. 
In this review, the function of gut microbiota and chronic diseases will be discussed along with possible treatments from the use of functional foods, medications, and therapies, in addition to an opinion regarding the investigation and treatment of IBD.

\section{WHAT IS INFLAMMATORY BOWEL DISEASE?}

Inflammatory bowel diseases (IBD) are a group of intestinal diseases characterized by chronic inflammation of the bowel associated with an abnormal immune response [2]. There are many triggers for IBD, including stress, changes in environment or diet, a pathogenic invasion, and stress. Genetic polymorphism, microbiota, and food hypersensitivity are factors which contribute to IBD pathology (T-Cell negative regulators, B Cells, epithelial junctions, innate sensors). Crohn's disease is characterized as a responsive disease for those at risk from pathogens, high intestinal permeability, genetic factors, the environment, dysbiosis, or bacterial translocation, in addition to inflammation [7].

In an article titled "Regional ileitis: a pathological and clinical entity that identified patients with a chronic inflammatory disease of unknown etiology," the disease was later described as Crohn's disease [22]. CD can occur anywhere along the digestive system [23]. Those affected have elevated levels of jejunal mucosa causing the reduced synthesis of brush border enzymes. Thus, Crohn's disease can be categorized as a diffuse lesion of the gastrointestinal tract [24].

Ulcerative colitis is an IBD present in the lining of the colon that causes chronic relapse or progressive inflammation and a decrease in microbiota diversity, especially among bacteria that produce butyrate, which represses pro-inflammatory cytokine secretion [25]. Steroids are often prescribed to control UC symptoms, despite well-known side effects including hyperglycemia, infections, bone loss, and more. [26].

All IBD can affect brain functions. For example, Zonis et. al discovered that UC can alter hippocampal neurogenesis due to a cyclin-dependent kinase inhibitor, p21, which can suppress neuronal cell proliferation. Unfortunately, p21 expression can increase due to inflammation [27]. Furthermore, conventional treatment by itself is unable to control the symptoms of IBD. In light of this, functional foods may potentially be used in addition to prescription medication. However, the amount, schedule, and particular foods capable of improving outcomes need to be identified. Interestingly, a study in women found that probiotic intake from fermented milk could alter brain activity in regions controlling emotion and sensory processing [28].

\section{METHODS OF DIAGNOSIS}

IBD is diagnosed using Magnetic resonance heterography (MRE) and Wireless capsule endoscopy (WCE). WCE is a user and patient-friendly sensor diagnosis that assists in diagnosing the severity of IBD when ingested [29]. Magnetic resonance heterography (MRE) has been proven to be helpful in the diagnosis of IBD and CT. Diagnostic techniques have been very useful in respect to $\mathrm{CD}$ cross sectional diagnosis, in addition to extra-intestinal and extra-luminal conditions.

However, these techniques make children more prone to CD due to ionizing radiation [30]. Fortunately, MRE is radiation free and constructs the same results as CT and MRI [30-32]. Another diagnostic method is confocal laser-induced endomicroscopy, which was introduced to capture 
images of "virtual histology" of the gastrointestinal mucosa [33]. The benefits and limitations of various diagnostic techniques are shown in Table 1.

Table 1. Comparison of a few IBD diagnosis methods.

\begin{tabular}{|c|c|c|}
\hline Diagnosis Method of IBD & Pros & Cons \\
\hline $\begin{array}{l}\text { Wireless Capsule Endoscopy } \\
\text { (WCE) }\end{array}$ & - Can visualize small bowel mucosa & $\begin{array}{l}\text { - Difficulty in differentiating } \\
\text { ulcers from CD } \\
\text { - } 13 \% \text { risk of capsule retention in } \\
\text { CD patients }\end{array}$ \\
\hline $\begin{array}{l}\text { Magnetic Resonance } \\
\text { Enterography (MRE) }\end{array}$ & $\begin{array}{c}\text { - Diagnose IBD inflammation in CD } \\
\text { - Increase of blood flow could signal } \\
\text { inflammation phase }\end{array}$ & $\begin{array}{l}\text { - Lower visual quality of images in } \\
\text { contrast to CT } \\
\text { - Difficult to differentiate between } \\
\text { inflammation and fibrosis }\end{array}$ \\
\hline Computed Tomography (CT) & $\begin{array}{l}\text { - Identify strictures, abscesses, and } \\
\text { fistulae } \\
\text { - Identify severity of CD }\end{array}$ & $\begin{array}{l}\text { - May not detect early symptoms } \\
\text { of CD as an MRE diagnosis } \\
\text { - } 0.08 \% \text { risk of cancer from } \\
\text { radiation exposure }\end{array}$ \\
\hline $\begin{array}{l}\text { Confocal Laser-Induced } \\
\text { Endomicroscopy }\end{array}$ & $\begin{array}{l}\text { - Allow visualization of the } \\
\text { pathology of mucosal } \\
\text { epithelium } \\
\text { - Manage IBD patients } \\
\text { - Predict future relapse of the disease } \\
\text { - Responses of anti-TNF therapy }\end{array}$ & $\begin{array}{l}\text { - Limited equipment and training } \\
\text { in general practice }\end{array}$ \\
\hline
\end{tabular}

A recent large international study which investigated 34,819 patients with IBD genotyped by gene-microarray methodology was able to detect three phenotypic-location associations which categorized IBD as ileal Crohn's disease, colonic Crohn's disease, and ulcerative colitis [34]. The mathematical analysis of relatives with or without UC and or IBD has demonstrated that they share similar intestinal microbiota. In contrast, there are no relationships in non-relatives with or without IBD shared similar microbiota [35]. This relationship in microbiota is considered a biomarker of UC disease activity [35]. As for ulcerative colitis, assessing its severity includes the frequency of bowel movements, extent of rectal bleeding, endoscopic appearance, and effects on the patient's quality of life and activities [36]. Because UC can relapse, using plasma free amino acid concentrations can predict the risk of relapse within a year of diagnosis. Additionally, this study also associated decreased histidine levels in PFAAs as a marker of an increased risk of relapse [37]. IBD in children has been difficult to diagnose, due to how there are no chronic symptoms in the early stages of IBD. However, colonic crypt distortion or rectosigmoid eosinophilia may be early signs of IBD in children [35-8]. Fecal lactoferrin can be used to detect IBD in pediatric patients, as patients with IBD will express increased levels of this inflammatory marker. This has also been demonstrated in both UC and CD [39]. Another diagnostic method is ${ }^{1} \mathrm{H}$ NMR, which is able to show inflammation-driven changes in the metabolic profile that are related to malabsorption and dysbiosis [40].

Microbial communities throughout the gut are evaluated using bacterial 16S ribosomal RNA gene sequencing, which act as a phylogenetic marker of microbiota that show there are different 
mucus phenotypes, in addition to a difference in permeability. Limitations of the 16S RNA gene sequencing include its lack of diversity, specificity, and comparison of databases, in addition to this method also including many biases [41]. In a study employed on healthy patients with active and inactive UC, butyrate was shown to reduce the expression of pro-inflammatory cytokines by inhibiting the NF-kB pathway, causing an anti-inflammatory effect [42]. Individuals with a high gene count (HGC) for microbiota, have a microbiome rich in butyrate-producing organisms, in addition to having lower risk for metabolic disorders and obesity. On the contrary, low gene count (LGC) gut microbial individuals have higher proportions of pro-inflammatory bacteria like Bacteroides and Ruminococcus gnavus, which are associated with IBD [43]. Infections can also be used as an IBD diagnostic factor for undiagnosed disease [44-45]. There are a variety of IBD diagnostic methods, with each being discriminatory based on the level of frequency, age, or availability. Multiple scientific studies and clinical trials have shown results from diagnosis and possible treatments.

\section{FUNCTIONAL FOODS AND SYNBIOTICS}

Changes in diet can greatly affect the type of microbiota and can potentially reduce the severity of IBD symptoms [44]. Prebiotics are "non-viable food components that confer a health benefit on the host associated with modulation of the microbiota." By definition, prebiotics are not absorbed or hydrolyzed in the gastro-intestinal tract. Prebiotics constitute a selective substrate for one or a limited number of beneficial bacteria and are able to alter the colonic microbiota in favor of a healthier composition. The probiotics definition was originally framed by the World Health Organization (WHO) and Food and Agriculture Organization of the United Nations (FAO) as the following: "live microorganisms which, when administered in adequate amounts confer a health benefit on the host." Probiotics and prebiotics combined synergistically can be more effective than when taken alone [46]. Functional foods are classified by the Functional Food Center (USA) as "Natural or processed foods that contain known or unknown biologically-active compounds; which, in defined, effective non-toxic amounts, provide a clinically proven and documented health benefit for the prevention, management, or treatment of chronic disease" [47]. Functional foods can act as a natural dietary supplementation that assist microbiota in regulating the health of hosts. Probiotics and prebiotics can be found in functional foods and benefit the host. A diet consisting of whole-grains or prebiotics can decrease the amount of bacterial endotoxins released into the bloodstream and regulate levels of inflammation [48]. This kind of diet can also increase bacteria capable of producing beneficial products from the fermentation of those carbohydrates [48]. An important source of probiotics is yogurt. When yogurt is consumed, concentrations of Lactobacillus and Bifidobacterium in stool are increased and levels of Bacteroides are decreased [49]. Bacteroides are considered to be "aggressive" bacteria due to the implications in the pathogenesis of IBD and is observed in ratio with Firmicutes to demonstrate the status of microbiota [50].

There is evidence that algae could be beneficially effective towards IBD. Red seaweed includes many bioactive ingredients (sulfated polysaccharides, polyphenols, carotenoids, amino acids, protein/peptide, and lipids) and has the ability to beneficially change the mucosal barrier function in IBD [51]. Unfortunately, most people in western countries do not consume algae due to a lack of awareness and/or dietary customs. Asian countries consume this product abundantly and research has shown that traditional Asian diets are associated with a reduced risk of cancer, and diabetes. Additionally, diets that contain red seaweed confer anti-inflammatory, immunomodulatory, and neuroprotective effects through its prebiotic and antioxidant properties. 
Food and medical industries have become increasingly interested in investigating related organisms for undiscovered bioactive compounds or nutrients [51].

Brown algae, Dictyopteris undulata, contain sesquiterpene zonarol, which works by inhibiting inflammation and the apoptosis responsible for disrupting the mucosal barrier function. Currently, 5-amin osalicylic acid (5-ASA) is used to inhibit inflammation. However, zonarol has the potential to be a suggested change [52]. A study conducted by Kang et al. investigated whether brown algae extract could induce apoptosis through inducing endoplasmic reticulum (ER) stress in human colonic cancerous cells. ER stress can be overwhelming and lead to the apoptotic death of a damaged cell [53]. Red algae consists of agarose and agarose oligosaccharides, which have demonstrated prebiotic effects. Fortunately, Bacteroides uniformis (L8), which is occasionally found in the gut, can degrade these compounds leading to antioxidant, anti-tumor, and antiinflammatory effects [54]. Carbohydrate active enzymes, CAZymes that extract energy from polysaccharides suggest that the human microbiome has evolved with the ability to degrade algal carbohydrates [55]. Fucoidans, fructose-rich polysaccharides, are found in edible brown algae and have been known to have substantiality-inflammatory effects. A study by Lean et al. treated mice with fucoidans and monitored the signs of colitis for any effect the fucoidans may have towards inflammation. Fucoidans reduced colitis symptoms, diarrhea, and the relative weight of the colon and spleen, implying they had reduced inflammation and edema [56].

Vitamin D is a bioactive signaling compound that modulates inflammatory responses via regulation of pro-inflammatory gene expressions, their transcription factors, and the activation of signaling cascades that mediate inflammatory responses [57]. Vitamin D supplementation has the potential for efficient therapeutic use, due to its ability to stimulate the production of T-regulatory lymphocytes and assists with recovery from IBD [58]. Low vitamin D levels are associated with increased cancer and IBD risk. Furthermore, higher levels of vitamin D are associated with reduced risks of Clostridium difficile [59].

Oxidative stress (OS) can have a negative impact in IBD because it can lead to tissue damage. Interestingly, extra virgin olive oil could increase antioxidant enzyme activity, modulate responses against OS, and reduce the effects of IBD [60]. A study conducted by Bouzid et al. used malondialdehyde (MDA) as a biological marker to identify IBD [61]. A marker of lipid peroxidation, MDA indicates the presence of oxidative stress and suggests that oxygen radicals are released in the inflammatory process associated with IBD [58]. There are some dietary fats that have been necessary or beneficial in treating health issues. However, omega-3 polyunsaturated fatty acid effects differ by location in IBD and induce changes to microbiota that can cause pro/anti-inflammatory effects [62].

Dioscoreaceae, is a type of yam plant with the bioactive compound methyl protodioscin (MPD), a substance shown to be beneficial in treating IBD [63]. In mice, colitis was induced using dextran sulfate sodium and subsequently treated with MPD [63]. MPD ameliorated inflammation in the intestinal mucosa by enhancing intestinal barrier differentiation. Furthermore, MPD protected colonic mucosa from Citrobacter rodentium, while also preventing the colonization of bacteria [63]. Another study by Gil et. al focused on how this type of yam plant extract effected mice via the down-regulation of genes that were related to inflammation [64].

C. difficile is a gram-positive, anaerobic, and dormant spore-forming bacterium, which can cause many infections and gastroenteritis-associated deaths because of its natural antibiotic resistance and ability to spread spores [65]. Intestinal microbiota can fight against $C$. difficile through resource competition, inhibition of germination or vegetative growth, or enhancement of the host's defenses [66]. Increased use of antibiotics may increase $C$. Difficile incident in healthy 
individuals by damaging microbiota [67]. Patients with UC have higher risk of $C$. difficile infection (CDI) and the outcomes can be significantly more severe [68]. To correct the imbalance and restore the health of intestinal microbiota, CDI can be treated using fecal microbial transport (FMT). [69]. Additionally, other alternative methods of treating ulcerative colitis or Crohn's disease can be seen in Tables 2 and 3. Each table lists functional food ingredients that have known possible effects on IBD.

Table 2. The effects of functional food ingredients on Ulcerative Colitis

\begin{tabular}{|c|c|c|c|c|c|c|c|}
\hline Reference & Analysts & $\mathbf{n}$ & Subject & $\begin{array}{l}\text { Duratio } \\
\text { n }\end{array}$ & $\begin{array}{l}\text { Interventio } \\
\text { n }\end{array}$ & Outcome & Study \\
\hline $\begin{array}{l}\text { Kruis, } \\
1997[73]\end{array}$ & $\begin{array}{l}\text { Probiotic } \\
\mathrm{S}\end{array}$ & $\begin{array}{l}12 \\
0\end{array}$ & $\begin{array}{l}120 \text { human } \\
\text { subjects } \\
\text { with } \\
\text { chronic UC }\end{array}$ & $\begin{array}{l}12 \\
\text { weeks }\end{array}$ & $\begin{array}{l}500 \mathrm{mg} \\
\text { mesalazine } \\
\text { t.d.s. or } 200 \\
\text { mg E. coli } \\
\text { Nissle }\end{array}$ & $\begin{array}{l}\text { Probiotic treatment is } \\
\text { an alternative option in } \\
\text { maintenance therapy } \\
\text { for UC. Relapse rate: } \\
11.3 \% \text { and } 16.0 \% \\
\text { mesalazine and E. coli } \\
\text { Nissle, respectively }\end{array}$ & Double-blind comparison \\
\hline $\begin{array}{l}\text { Langmead, } \\
2004[74]\end{array}$ & $\begin{array}{l}\text { Aloe } \\
\text { Vera }\end{array}$ & 44 & $\begin{array}{l}44 \text { human } \\
\text { subjects } \\
\text { with active } \\
\text { UC }\end{array}$ & 4 weeks & $\begin{array}{l}\text { Aloe vera } \\
\text { gel } 100 \mathrm{~mL} \\
\text { twice daily }\end{array}$ & $\begin{array}{l}\text { Reduces histological } \\
\text { disease activity and } \\
\text { provides inflammation } \\
\text { inhibiting properties. } \\
\text { More research is } \\
\text { needed to see if the } \\
\text { results stop if the } \\
\text { intervention ceases }\end{array}$ & $\begin{array}{l}\text { Double-blind, randomize, } \\
\text { placebo controlled trial }\end{array}$ \\
\hline $\begin{array}{l}\text { Hanai, } \\
2006[75]\end{array}$ & $\begin{array}{l}\text { Curcumi } \\
\mathrm{n}\end{array}$ & 45 & $\begin{array}{l}45 \text { human } \\
\text { subjects } \\
\text { with UC }\end{array}$ & $\begin{array}{l}6 \\
\text { months }\end{array}$ & $\begin{array}{l}1 \mathrm{~g} \\
\text { curcumin } \\
\text { twice daily } \\
\text { plus } \\
\text { mesalamine } \\
\text { or placebo }\end{array}$ & $\begin{array}{l}\text { Curcumin significantly } \\
\text { improved both clinical } \\
\text { activity and endoscopic } \\
\text { indexes. Curcumin in } \\
\text { combination with } \\
\text { mesalamine better in } \\
\text { comparison to placebo. } \\
\text { More research is } \\
\text { needed to see if the } \\
\text { results stop if the } \\
\text { intervention ceases }\end{array}$ & $\begin{array}{l}\text { Randomized, double-blind, } \\
\text { placebo-controlled trial }\end{array}$ \\
\hline $\begin{array}{l}\text { Kanauchi, } \\
2003[76]\end{array}$ & $\begin{array}{l}\text { Germinat } \\
\text { ed barley } \\
\text { foodstuff }\end{array}$ & 21 & $\begin{array}{l}21 \text { patients } \\
\text { with mild- } \\
\text { moderate } \\
\text { active UC }\end{array}$ & $\begin{array}{l}24 \\
\text { weeks }\end{array}$ & $\begin{array}{l}20-30 \mathrm{~g} \text { of } \\
\text { germinated } \\
\text { barley } \\
\text { foodstuff } \\
\text { with } \\
\text { continuation } \\
\text { of baseline } \\
\text { steroid } \\
\text { treatment }\end{array}$ & $\begin{array}{l}\text { Decrease clinical } \\
\text { activity index (degree } \\
\text { of visible blood in } \\
\text { stools and diarrhea). } \\
\text { More research is } \\
\text { needed to see if the } \\
\text { results stop if the } \\
\text { intervention ceases }\end{array}$ & Multicenter Open Trial \\
\hline $\begin{array}{l}\text { Kazi, } 2009 \\
{[77]}\end{array}$ & $\begin{array}{l}\text { Saffron } \\
\text { (crocetin } \\
\text { extract) }\end{array}$ & 10 & $\begin{array}{l}10 \text { female } \\
\text { BALB } \\
\text { mice } \\
\text { induced } \\
\text { with UC }\end{array}$ & 8 days & $\begin{array}{l}25,50, \text { or } \\
100 \mathrm{mg} / \mathrm{kg} / \mathrm{d} \\
\text { of crocetin }\end{array}$ & $\begin{array}{l}50 \mathrm{mg} / \mathrm{kg} / \mathrm{d} \text { was the } \\
\text { most effective dose of } \\
\text { crocetin in the mice. } \\
\text { Reduction in neutrophil } \\
\text { infiltration, lipid } \\
\text { peroxidation, nitric } \\
\text { oxide levels, also down } \\
\text { regulation of nuclear } \\
\text { factor-kB with } \\
\text { favorable expression of } \\
\text { TH1 and TH2. More } \\
\text { research is needed if }\end{array}$ & In vivo trial \\
\hline
\end{tabular}




\begin{tabular}{|l|l|l|l|l|l|l|}
\hline & & & & & $\begin{array}{l}\text { the results stop when } \\
\text { intervention ceases }\end{array}$ & \\
\hline
\end{tabular}

Table 3. The effects of functional food ingredients on Crohn's Disease

\begin{tabular}{|c|c|c|c|c|c|c|c|}
\hline Reference & Analysts & $\mathbf{n}$ & Subject & Duration & Intervention & Outcome & Study \\
\hline $\begin{array}{l}\text { Yang, } 2013 \\
\text { [78] }\end{array}$ & Vitamin D & 18 & $\begin{array}{l}18 \text { human } \\
\text { subjects with } \\
\text { confirmed } \\
\text { Crohn's } \\
\text { disease } \\
\text { between 18- } \\
70 \text { years old }\end{array}$ & 24 weeks & $\begin{array}{l}\text { Vitamin D3 initiated } \\
\text { at } 1,000 \mathrm{IU} / \mathrm{d} \text {. After } \\
2 \text { weeks, } \\
\text { incrementally } \\
\text { increased to } \\
\text { maximum } 5,000 \\
\text { IU/d. }\end{array}$ & $\begin{array}{l}\text { A safe dose to } \\
\text { induce remission } \\
\text { in mild-to- } \\
\text { moderate CD is } \\
5,000 \mathrm{IU} / \mathrm{d}\end{array}$ & Clinical Trial \\
\hline $\begin{array}{l}\text { Kaliora, } 2007 \\
{[79]}\end{array}$ & Mastic & 10 & $\begin{array}{l}10 \text { patients } \\
\text { with mild- } \\
\text { moderate } \\
\text { active } \\
\text { Crohn's } \\
\text { Disease }\end{array}$ & 4 weeks & $\begin{array}{l}2.2 \text { g mastic daily ( } 6 \\
\text { caps total) }\end{array}$ & $\begin{array}{l}\text { Mastic } \\
\text { supplementation } \\
\text { concluded as a } \\
\text { tumor necrosis } \\
\text { factor- } \alpha \\
\text { inhibitor and } \\
\text { migration } \\
\text { inhibitory factor } \\
\text { stimulator }\end{array}$ & $\begin{array}{l}\text { Double-blind, } \\
\text { randomized } \\
\text { placebo- } \\
\text { controlled trial }\end{array}$ \\
\hline $\begin{array}{l}\text { Omer, } 2007 \\
{[80]}\end{array}$ & $\begin{array}{l}\text { Wormwood } \\
\text { herb and } \\
\text { prednisone }\end{array}$ & 40 & $\begin{array}{l}40 \text { patients } \\
\text { with } C D\end{array}$ & 20 weeks & $\begin{array}{l}3 \text { weeks } 40 \mathrm{mg} \\
\text { prednisone and } \\
\text { wormwood herb } 3 \mathrm{x} \\
500 \mathrm{mg} / \mathrm{d} \text { for } 10 \\
\text { weeks. 5- } \\
\text { aminosalicylates for } \\
\text { at least } 4 \text { weeks, } \\
\text { azathioprine at least } \\
8 \text { weeks, or } \\
\text { methotrexate for at } \\
\text { least } 6 \text { weeks as } \\
\text { concomitant } \\
\text { medications }\end{array}$ & $\begin{array}{l}\text { Remission of CD } \\
\text { symptoms and a } \\
\text { strong } \\
\text { suggestion that } \\
\text { wormwood herb } \\
\text { has a steroid } \\
\text { sparing effect }\end{array}$ & $\begin{array}{l}\text { Double-blind, } \\
\text { randomized } \\
\text { placebo- } \\
\text { controlled }\end{array}$ \\
\hline $\begin{array}{l}\text { Ren, } 2013 \\
{[81]}\end{array}$ & $\begin{array}{l}\text { Tripterygium } \\
\text { wilfordii } \\
(\mathrm{GTW})\end{array}$ & 45 & $\begin{array}{l}45 \\
\text { postoperative } \\
\text { CD patients } \\
\text { between the } \\
\text { ages } 18-60\end{array}$ & 52 weeks & $\begin{array}{l}1 \mathrm{mg} / \mathrm{kg} \text { GTW or } 4 \\
\mathrm{~g} 5 \text {-ASA daily for } \\
52 \text { weeks. Baseline } \\
\text { analysis at weeks } \\
13,26 \text {, and } 52\end{array}$ & $\begin{array}{l}\text { GTW was more } \\
\text { effective than 5- } \\
\text { ASA in } \\
\text { minimizing } \\
\text { clinical and } \\
\text { endoscopic } \\
\text { recurrence of CD }\end{array}$ & $\begin{array}{l}\text { Prospective, } \\
\text { single-center, } \\
\text { randomized } \\
\text { single-blind } \\
\text { study }\end{array}$ \\
\hline $\begin{array}{l}\text { Holtmeier, } \\
2011 \text { [82] }\end{array}$ & $\begin{array}{l}\text { Boswellia } \\
\text { serrata }\end{array}$ & 108 & $\begin{array}{l}108 \text { patients } \\
\text { with active } \\
\text { Crohn's } \\
\text { disease }\end{array}$ & 52 weeks & $\begin{array}{l}2400 \mathrm{mg} / \mathrm{d} \text { or } \\
\text { placebo to check for } \\
\text { maintaining } \\
\text { remission }\end{array}$ & $\begin{array}{l}\text { There was no } \\
\text { distinguishable } \\
\text { difference or } \\
\text { superiority } \\
\text { between the } \\
\text { placebo and } \\
\text { boswellian } \\
\text { serrata }\end{array}$ & $\begin{array}{l}\text { Randomized } \\
\text { double-blind, } \\
\text { placebo- } \\
\text { controlled, } \\
\text { parallel study }\end{array}$ \\
\hline
\end{tabular}

Phytochemicals found in cocoa and in red wine contain antioxidants beneficial to intestinal and overall health. Some polyphenols have antioxidant activities. In particular, cocoa is rich in polyphenols that contain antioxidant, anti-inflammatory, and antitumor qualities. These can help prevent tumor formation in UC patients who are at risk of developing colorectal cancer due to blocked expression of a signal transducer and transcription activation in the intestinal epithelial cells that take part in IBD and colorectal cancer [70]. The abundant non-alcoholic polyphenol portion of red wine includes: falvan-3-ol, flavanols, anthocyanins, catechin, epicatechin, 
proanthocyanadins, benzoic, and hydroxycinnamic acids. Red wine can prevent or delay the progression of IBD by reducing oxidative stress and inflammation through polyphenols acting as free radical scavengers and modulators of inflammation-related genes [71]. Additionally, red wine derived polyphenols can also act as prebiotics and antimicrobial agents. The alcohol within red wine at low concentrations can alter gastrointestinal (GI) pathogens such as Salmonella enterica and E. coli [71]. Fiscus bengalensis refers to the "banyan tree" that produces sap from the bark, which also has an antioxidant phenolic compound that can assist towards the treatment of inflammation, dysentery, and diarrhea in IBD patients [72].

\section{NUTRITION interventions for IBD}

Prebiotics, probiotics, and synbiotics can have a beneficial temporary effect towards IBD. However, fecal transplants also show promise. FMT, which is also known as bacteriotherapy, is a process of donating fecal material to the intestinal tract of a patient [85]. The FDA initially classified human fecal material as drugs due to its medical usage. As fecal material is now considered a human tissue, FMT is easier to perform as there is no drug-regulation policy for human tissue [85]. The first fecal transplant was recorded in 1989 when a man with ulcerative colitis conducted a self-administered fecal microbiota transplant (FMT) on himself from a healthy donor, which reduced symptoms and induced remission [83]. In another case, an individual with C. difficile and chronic IBD underwent FMT as a rescue therapy, which led to remission and improved overall well-being [84]. A study conducted in IBD patients who had fecal transplants indicated that the procedure was associated with clinical remission and improvement in CD and $\mathrm{UC}[84]$.

E. coli strain Nissle 1917 has been identified as clinically effective towards IBD because it has been reported to be equivalent to Mesalazine (an anti-inflammatory drug) treatment for patients with UC but not CD [86]. As E. coli strain Nissle 1917 is an apathogenic strain that lives in an anaerobic environment, it can thrive in the large intestine as a carrier of specific molecules into the intestine, often in places where a carrier and its products are undesirable [86]. E. coli strains can multiply rapidly, adhere, and invade epithelial cells, negatively modify the intestinal barrier function, or induce inflammatory responses in cells [86]. All animals, including cold-blooded animals, are infected with $E$. coli, which is usually the first bacterium to colonize the body once nutrients are obtained from the mucus layer [86]. E. coli is resistant to the acid contained in the stomach through a protective system and can use the mucus layer to colonize itself, in addition to acting as a nutrient reservoir [86].

Faecalibacterium prausnitzii ( $F$. prausnitzii) is a butyrate-producing species that can induce gut homeostasis and has a protective role in IBD, especially CD [87]. Miquel et al. conducted a study that involved colitis affected mice prone to this bacterial species, discovering there was a protective modulation of metabolites along the gastrointestinal tract, reducing colitis [88]. This species, along with Clostridium leptum, are not very abundant in fecal samples in IBD patients, especially CD patients, due to the numerous butyrate-producing bacteria. However, they represent a huge source of energy for colonic epithelial cells and are associated with the inhibition of inflammation [89].

Medications used for IBD treatment depend on the severity and location of the lesion and include amino salicylates and antibiotics when the disease is limited to the mucosa, corticosteroids for moderate severe cases, and biological molecules when fistula is present [90]. Biological therapies include the use of antibodies to inhibit pro-inflammatory cytokines, such as tumor necrosis factor alpha $(\mathrm{TNF} \alpha)$ that can induce apoptosis or block growth factors and induce remission of IBD [91]. Adalimumab is anti-TNF $\alpha$, which has been shown to maintain remission in $\mathrm{CD}$, even in severe cases [92]. With respect to CDI (Clostridium difficile infection), especially 
in IBD, vancomycin treatment is often successful. According to a study conducted by Horton et al., subjects treated with this antibiotic showed fewer readmissions and shorter lengths of hospital stays, especially when steroids were not used concomitantly, as steroids increased the severity and risk of CDI [93]. Antibiotics are a common form of therapy in CDI, but they can change the environmental conditions for microbiota and even trigger resistance [94]. Furthermore, antibiotics can affect the fecal environment and reduce the numbers of butyrate-producing species [95]. However, biosynthesis of antibiotics in the gut does not occur naturally, which suggests that antibiotic resistant genes are controlled independently by the presence of antibiotics. This is consistent with the rich expression of these genes in the intestinal area [96]. On the other hand, antibiotics are presumed to potentially induce beneficial effects in the treatment of active luminal CD via alteration of microbiota [97]. Metronidazole has been used in multiple studies to treat CD. One study found no objective difference in patients treated with Metronidazole, although patients did report an enhanced feeling of well-being and comfort [98]. In a crossover study using metronidazole and sulphasalazine, metronidazole was shown to be more effective [99]. An additional study compared metronidazole and cotrimoxazole separately and together, and consequently detected no significant differences [100]. Overall, metronidazole was determined to be beneficial towards the suppression of $C D$ via fighting anaerobic bacteria and possibly acting as an immunosuppressant rather than an antibiotic [98].

There are other medications that have been found to cause changes in IBD, either through changing the disease course or by inducing remission. Monoclonal antibodies have also been shown to be beneficial in treating IBD patients. Examples include golimumab, natalizumab, vedolizumab, and biosimilars. Golimumab is an anti-TNF monoclonal antibody that was shown to be effective in reducing symptoms, inducing remission, and mucosal healing in UC patients [101]. Anti-TNF therapy has been shown to induce mucosal healing in IBD patients [102]. However, some CD and UC patients do not respond to this treatment [102]. Natalizumab is another monoclonal antibody that prevents symptoms of Crohn's disease and regulates $\alpha_{4}$ integrin whose expression in endothelium luminal cells causes inflammation in IBD [103]. Vedolizumab is a monoclonal antibody which, similarly to Natalizumab, is specific towards $\alpha 4 \beta 7$ integrin which associates itself with inflammation of the intestinal epithelium [104]. Vedolizumab can induce clinical remission and mucosal healing within a year of exposure [105]. Lastly, biosimilars are copy versions of biological drugs targeting liver and gastrointestinal diseases, whose amino acid and glycosylation patterns are similar to other licensed medications [106]. According to the European Crohn's and Colitis Organization, biosimilars may be effective and safe for some causes but potentially not for others. Consequently, the accurate assessment of their strengths and weaknesses is needed in order to benefit patients [106]. Overall, medications and/or antibiotics can have positive therapeutic effects.

Herbal therapy has been categorized as a natural agent supporting IBD treatment. It is considered to be a complementary and alternative medicine (CAM), as it is administered outside of centers where conventional medicine is provided [107]. A study investigating the effects of herbal medicine in IBD patients indicated that these substances could be more effective than other CAM, representing a more cost efficient alternative [108]. Traditional Chinese medicine (TCM) diagnoses and treats symptoms through inspection, listening, smelling, inquiry, and palpitation [109]. TCM uses YunNan BaiYao (YNBY), Wedelia chinensis, Changtai granules, and Xilei-san. YNBY is a mix of different herbs and plants, which can suppress the severity of colitis through immune-suppression and wound-healing mechanisms [110]. W. chinensis water extract is beneficial through relief of diarrhea, rectal bleeding, body weight loss, and colonic inflammation [110]. Changtai granules (CTG), exhibits anti-diarrheal, anti-inflammatory, anti-bacterial, and analgesic effects [110]. Xilei-san (traditional Chinese herb) is another type of TCM that was found 
to reduce inflammation in colitis patients administered together with mesalazine or corticosteroids in a clinical trial, $86 \%$ of patients went through remission, suggesting that Xilei-san had remission potential [110]. Therefore, herbal medicine demonstrates favorable outcomes in IBD patients,

The introduction of stem cells may be an alternative treatment of IBD. Differentiation of hematopoietic and non-hematopoietic stem cells are likely involved in the pathogenesis of IBD [111]. Hematopoietic stem cells (HSC) and mesenchymal stem cells (MSC), are involved in resetting the immune system of patients on myeloablation therapy, which causes elimination of Tlymphocyte and memory T-cells [112]. Mesenchymal stromal cells are adult stem cells that can have multiple effects towards the immune system including activation, proliferation, or repair of tissue. Furthermore, these cells can have anti-inflammatory effects in IBD patients [113]. Once a patient receives transplanted MSC's, remission will begin, accompanied by the release of antiinflammatory cytokines to balance the immune system [114]. PROM1 has been identified and used as a stem cell marker for prediction of colon cancer or IBD, but can possibly assist in intestinal healing [115]. Bone marrow stem cells may be able to regenerate damaged mucosa in the gastrointestinal tract and restore damaged intestinal permeability [116]. Table 4 describes more common nutrition approaches that may be beneficial or ineffective.

Table 4. Common Nutritional Approaches

\begin{tabular}{|c|c|c|}
\hline Alternative Therapies & Pros & Cons \\
\hline Probiotics [117] & $\begin{array}{l}\text { - Adding beneficial bacteria, in } \\
\text { the digestive tract may have } \\
\text { beneficial effect against IBD } \\
\text { - There is some evidence to } \\
\text { support these claims }\end{array}$ & $\begin{array}{l}\text { - } \\
\text { - } \\
\text { Doesearch is limited have significant } \\
\text { evidence to support the } \\
\text { benefits of probiotics } \\
\text { - } \quad \begin{array}{l}\text { Probiotics therapy is not } \\
\text { regulated by the FDA }\end{array} \\
\text { - May have unknown side } \\
\text { effects }\end{array}$ \\
\hline Fish Oil [118] & $\begin{array}{l}\text { - Fish oil present anti- } \\
\text { inflammatory activities } \\
\text { - Combining fish oil with } \\
\text { aminosalicylates increases } \\
\text { effectiveness }\end{array}$ & $\begin{array}{l}\text { - } \text { May cause diarrhea } \\
\text { - Limited evidence that proves } \\
\text { its claims } \\
\text { - Fish Oil therapy is not } \\
\text { regulated by the FDA } \\
\text { - May have unknown side } \\
\text { effects }\end{array}$ \\
\hline Aloe Vera [119] & $\begin{array}{l}\text { - Acts as a natural anti- } \\
\text { inflammatory for UC }\end{array}$ & $\begin{array}{l}\text { - } \quad \text { May cause diarrhea } \\
\text { - } \text { Aloe Vera therapy is not } \\
\text { regulated by the FDA } \\
\text { - May cause unknown side } \\
\text { effects }\end{array}$ \\
\hline
\end{tabular}




\begin{tabular}{|l|l|l|}
\hline Turmeric [120] & $\begin{array}{l}\text { The active ingredient in } \\
\text { turmeric, curcumin, has been } \\
\text { used in clinical trials of UC and } \\
\text { have shown promising results }\end{array}$ & $\begin{array}{l}\text { - Not significant evidence to } \\
\text { support the claims }\end{array}$ \\
& $\begin{array}{l}\text { Turmeric therapy is not } \\
\text { regulated by the FDA } \\
\text { May cause unknown side } \\
\text { effects } \\
\text { Research is limited }\end{array}$ \\
\hline
\end{tabular}

\section{SUMMARY}

IBD is a chronic disease that affects large numbers of individuals worldwide. Dysbiosis caused by antibiotics, diet, and genetic predisposition may increase the risk of acquiring IBD. Currently there are no treatments that are totally or uniformly effective for all forms of IBD, despite many clinical trials that have associated different pharmacological immunotherapy, natural medications, and other therapies. FMT is being studied for its potential to alleviate this disease, and has been shown to be effective. Unfortunately, most IBD patients are treated with bacterial therapeutics after serious symptoms are present. Thus, functional analysis, a method of studying interactions between microbes and diseases to analyze microbiome biological properties, should be used to observe metabolic shifts in intestinal microenvironments of IBD [122]. Existing biomarkers that distinguish CD from UC are limited in predicting the long-range course of a disease [123]. Therefore, research should be targeted at identifying markers of prognosis [123]. Consuming a healthy diet can also influence IBD, including consumption of functional foods. Enteral diets and semi-vegetarian diets, can increase the likelihood of remission in patients. Functional foods and bioactive compounds, such as probiotics or vitamins, have a significant effect in the regeneration of intestinal microbiota, which thereby causes remission or treatment of some IBD with respect to inflammation. Further studies are necessary to examine how microbes, bioactive components, and functional foods can be beneficial in facilitating anti-inflammatory responses, butyrate producing species, or restoration of mucosal barrier function and healing. As IBD is still an important disease, much research is required. This will be time-consuming as microbiota evolve and can become resistant to treatment. With ongoing investigation and persistence, the future of patients with IBD can be brighter.

List of Abbreviations: Complementary alternative medicine, CAM; Crohn's disease, CD; Clostridium difficile infection, CDI; Endoplasmic reticulum, ER; Food and Drug Administration, FDA; Fecal microbiota transplantation, FMT; Gastrointestinal, GI; Hematopoietic stem cells, HSC; Intestinal bowel disease, IBD; Low gene count, LGC; Malondialdehyde, MDA; Methyl protodioscin, MPD; Magnetic resonance enterography, MRE; Mesenchymal stem cells, MSC; PROM1Oxidative stress, OS; Traditional Chinese medicine, TCM; Tumor necrosis factor alpha, TNFa; Ulcerative colitis, UC; Wireless Capsule Endoscopy, WCE; YunNan BaiYao, YNBY; 5aminosalicylic acid, 5-ASA;

Competing Interests: The authors have no financial interests or any other conflicts of interest to disclose.

Authors' Contributions: All authors contributed to this review.

\section{REFERENCES}


1. Centers for Disease Control and Prevention [https://www.cdc.gov/ibd/ibdepidemiology.htm]

2. Distrutti E, Monaldi L, Ricci P, Fiorucci S: Gut microbiota role in irritable bowel syndrome: New therapeutic strategies. World J Gastroenterol. 2016 Feb 21; 22(7): 2219-2241.

3. Selber-Hnatiw S, et al.: Human Gut Microbiota: Toward an Ecology of Disease Front Microbiol. 2017; 8: 1265.

4. Hevia A, Bernardo D, Montalvillo E, et al.: Human Colon-Derived Soluble Factors Modulate Gut Microbiota Composition. Frontiers in Oncology. 2015; 5:86.

5. Wang W, Xu S, Ren Z, Jiang J, Zheng S: Gut microbiota and allogeneic transplantation. Journal of Translational Medicine. 2015; 13:275.

6. Ellis RJ, Bruce KD, Jenkins C, et al.: Comparison of the Distal Gut Microbiota from People and Animals in Africa. Ravel J, ed. PLoS ONE. 2013;8(1): 54783.

7. Carriere J, Darfeuille-Michaud A, Nguyen HTT. Infectious etiopathogenesis of Crohn's disease. World Journal of Gastroenterology: WJG. 2014;20(34): 12102-12117.

8. Malnick S, Melzer E: Human microbiome: From the bathroom to the bedside. World Journal of Gastrointestinal Pathophysiology. 2015;6(3): 79-85.

9. Neu J, Rushing J: Cesarean versus vaginal delivery: long term infant outcomes and the hygiene hypothesis. Clin Perinatol 2011, 38: 321-331.

10. Biasucci G, Benenati B, Morelli L, et al: Cesarean delivery may affect the early biodiversity of intestinal bacteria. J Nutr 2008, 138: 1796S-1800S.

11. Kanai T, Matsuoka K, Naganuma M, Hayashi A, Hisamatsu T: Diet, microbiota, and inflammatory bowel disease: lessons from Japanese foods. The Korean Journal of Internal Medicine. 2014, 29(4): 409-415.

12. Million, M. et al.: Gut bacterial microbiota and obesity. Clinical Microbiology and Infection, Volume 19, Issue 4, $305-313$.

13. Santacruz A, Collado MC, Garcia-Valdes L, et al.: Gut microbiota composition is associated with body weight, weight gain and biochemical parameters in pregnant women. British Journal of Nutrition. (2010), 104, 83-92.

14. Conlon MA, Bird AR: The impact of diet and lifestyle on gut microbiota and human health. Nutrients 2015, 7:17-44.

15. Cani PD, Neyrinck AM, Fava F, Knauf C, Burcelin RG, Tuohy KM, Gibson GR, et al.: Selective increases of bifidobacteria in gut microflora improve high-fat-diet-induced diabetes in mice through a mechanism associated with endotoxaemia. Diabetologia 2007, 50:2374-2383.

16. Cani PD, Amar J, Igles ias MA, Poggi M, Knauf C, Bastelica D, Neyrinck AM, et al.: Metabolic endotoxemia initiates obesity and insulin resistance. Diabetes 2007, 56: 17611772.

17. Neyrinck AM, Possemiers S, Verstraete W, de Backer F, Cani PD, Delzenne NM: Dietary modulation of clostridial cluster xiva gut bacteria (roseburia spp.) by chitin-glucan fiber improves host metabolic alterations induced by high-fat diet in mice. J Nutr Biochem 2012, 23: 51-59. 
18. Belizário JE, Napolitano M: Human microbiomes and their roles in dysbiosis, common diseases, and novel therapeutic approaches. Frontiers in Microbiology. 2015;6:1050.

19. Larsen PE, Dai Y: Metabolome of human gut microbiome is predictive of host dysbiosis. GigaScience. 2015; 4:42.

20. Varankovich NV, Nickerson MT, Korber DR: Probiotic-based strategies for therapeutic and prophylactic use against multiple gastrointestinal diseases.Frontiers in Microbiology. 2015; 6:685.

21. Mulak A, Bonaz B: Brain-gut-microbiota axis in Parkinson's disease. World Journal of Gastroenterology: WJG. 2015;21(37):10609-10620.

22. Geller SA, de Campos FPF: Crohn disease. Autopsy \& Case Reports. 2015;5(2):5-8.

23. Zhang F-M, Wang H-G, Wang M, Cui B-T, Fan Z-N, Ji G-Z: Fecal microbiota transplantation for severe enterocolonic fistulizing Crohn's disease. World Journal of Gastroenterology: WJG. 2013;19(41): 7213-7216.

24. Dunne WT, Cooke WT, Allan RN: Enzymatic and morphometric evidence for Crohn's disease as a diffuse lesion of the gastrointestinal tract. Gut. 1977;18(4):290-294.

25. Chen W-X, Ren L-H, Shi R-H: Enteric microbiota leads to new therapeutic strategies for ulcerative colitis. World Journal of Gastroenterology: WJG. 2014;20(42):15657-15663.

26. Cui B, Li P, Xu L, et al: Step-up fecal microbiota transplantation strategy: a pilot study for steroid-dependent ulcerative colitis. Journal of Translational Medicine. 2015; 13:298.

27. Zonis S, Pechnick RN, Ljubimov VA, et al.: Chronic intestinal inflammation alters hippocampal neurogenesis. Journal of Neuroinflammation. 2015; 12:65.

28. Tillisch K, Labus J, Kilpatrick L, et al.: Consumption of Fermented Milk Product With Probiotic Modulates Brain Activity. Gastroenterology. 2013;144(7):1394-401.

29. Carter D, Lang A, Eliakim R: Endoscopy in inflammatory bowel disease. A Journal of Gastroenterology, Nutrition and Dietetics. 2013;59(3):273-84.

30. Lee SM, Kim WS, Choi YH: Pediatric Magnetic Resonance Enterography: Focused on Crohn's Disease. Pediatric Gastroenterology, Hepatology \& Nutrition. 2015;18(3):149159.

31. Schleder S, Pawlik M, Wiggermann P et al: Interobserver Agreement in MR Enterography for Diagnostic Assessment in Patients with Crohn's Disease. Fortsc hr Röntgenstr. 2013; 185: 992-997.

32. Lee SM, Kim WS, Choi YH: Pediatric Magnetic Resonance Enterography: Focused on Crohn's Disease. Pediatric Gastroenterology, Hepatology \& Nutrition. 2015;18(3):149159.

33. Zimmermann EM, Al-Hawary MM: Magnetic resonance imaging of the small bowel in patients with Crohn's disease. Current opinion in gastroenterology. 2011;27(2):132-138.

34. Nguyen DL, Lee JG, Parekh NK, Samarasena J, Bechtold ML, Chang K: The current and future role of endomicroscopy in the management of inflammatory bowel disease. Annals of Gastroenterology: Quarterly Publication of the Hellenic Society of Gastroenterology. 2015;28(3):331-336. 
35. Fukuda K, Fujita Y: Determination of the discriminant score of intestinal microbiota as a biomarker of disease activity in patients with ulcerative colitis.BMC Gastroenterology. 2014; $14: 49$.

36. Cleynen I: Inherited determinants of Crohn's disease and ulcerative colitis phenotypes: a genetic association study. The Lancet. 2015.

37. Lichtenstein GR, Moderator MD, Hanauer SB, et al.: Emerging Treatment Options in Mild to Moderate Ulcerative Colitis. Gastroenterology \& Hepatology. 2015; 11(3 Suppl 1): 1-16.

38. Hisamatsu T, Ono N, Imaizumi A, Mori M, Suzuki H, Uo M, et al: Decreased Plasma Histidine Level Predicts Risk of Relapse in Patients with Ulcerative Colitis in Remission. PLoS ONE. 2015 10(10): e0140716.

39. Bass JA, Friesen CA, Deacy AD, et al.: Investigation of potential early Histologic markers of pediatric inflammatory bowel disease. BioMed Central Gastroenterology. 2015 Oct $13 ; 15(1): 129$.

40. Borkowska A, Liberek A, Luczak G, et al.: Fecal lactoferrin, a marker of intestinal inflammation in children with inflammatory bowel disease. Acta Biochimica Polonica. 2015;62(3):541-5.

41. Poretsky R, Rodriguez-R LM, Luo C, Tsementzi, Konstantinidis KT: Strengths and limitations of $16 \mathrm{~S}$ rRNA gene amplicon sequencing in revealing temporal microbial community dynamics. PLoS One 2014, 9:e93827.

42. Bjerrum JT, Wang Y, Hao F, et al.: Metabonomics of human fecal extracts characterize ulcerative colitis, Crohn's disease and healthy individuals.Metabolomics. 2015; 11:122-133.

43. Haag L-M, Siegmund B: Intestinal Microbiota and the Innate Immune System - A Crosstalk in Crohn's Disease Pathogenesis. Frontiers in Immunology. 2015; 6:489.

44. Jandhyala SM, Talukdar R, Subramanyam C, Vuyyuru H, Sasikala M, Reddy DN: Role of the normal gut microbiota. World Journal of Gastroenterology: WJG. 2015;21(29):87878803.

45. Hutfless S, Abramson O, Heyman MB, et al.: Infections Requiring Hospitalization as Predictors of Pediatric-Onset Crohn's Disease and Ulcerative Colitis. Gastroenterology Research and Practice. 2015:690581.

46. McCabe L, Britton RA, Parameswaran N: Prebiotic and Probiotic Regulation of Bone Health: Role of the Intestine and its Microbiome. Current Osteoporosis Reports. 2015 Dec;13(6):363-71.

47. Martirosyan D, Singh J: A new definition of functional food by ffc: What makes a new definition unique? Journal of Functional Foods in Health and Disease. 2015; 5(6): 209-223.

48. Zhang C, Yin A, Li H, et al.: Dietary Modulation of Gut Microbiota Contributes to Alleviation of Both Genetic and Simple Obesity in Children. EBioMedicine. 2015;2(8):966982.

49. Shadnoush M, Hosseini RS, Khalilnezhad A, et al.: Effects of Probiotics on Gut Microbiota in Patients with Inflammatory Bowel Disease: A Double-blind, Placebo-controlled Clinical Trial.The Korean Society of Gastroenterology. 2015;65(4):215-21. 
50. Kabeerdoss J, Jayakanthan P, Pugazhendhi S, Ramakrishna BS: Alterations of mucosal microbiota in the colon of patients with inflammatory bowel disease revealed by real time polymerase chain reaction amplification of $16 \mathrm{~S}$ ribosomal ribonucleic acid. The Indian Journal of Medical Research. 2015;142(1):23-32.

51. Cian RE, Drago SR, Sánchez de Medina F, Martínez-Augustin O: Proteins and Carbohydrates from Red Seaweeds: Evidence for Beneficial Effects on Gut Function and Microbiota. Barrow C, ed. Marine Drugs. 2015;13(8):5358-5383.

52. Yamada S, Koyama T, Noguchi H, et al.: Marine Hydroquinone Zonarol Prevents Inflammation and Apoptosis in Dextran Sulfate Sodium-Induced Mice Ulcerative Colitis. Arafa HMM, ed. PLoS ONE. 2014;9(11):e113509.

53. Kang KA, Kim JK, Jeong YJ, Na S-Y, Hyun JW: Dictyopteris undulata Extract Induces Apoptosis via Induction of Endoplasmic Reticulum Stress in Human Colon Cancer Cells. Journal of Cancer Prevention. 2014;19(2):118-124.

54. Li M, Li G, Zhu L, et al.: Isolation and Characterization of an Agaro-Oligosaccharide (AO)Hydrolyzing Bacterium from the Gut Microflora of Chinese Individuals. D'Auria S, ed. PLoS ONE. 2014;9(3):e91106.

55. Hehemann J-H, Kelly AG, Pudlo NA, Martens EC, Boraston AB: Bacteria of the human gut microbiome catabolize red seaweed glycans with carbohydrate-active enzyme updates from extrinsic microbes. Proceedings of the National Academy of Sciences of the United States of America. 2012;109(48):19786-19791

56. Lean QY, Eri RD, Fitton JH, Patel RP, Gueven N: Fucoidan Extracts Ameliorate Acute Colitis. Siegmund B, ed. PLoS ONE. 2015;10(6):e0128453.

57. Wobke TK, Sorg BL, Steinhilber D: Vitamin D in inflammatory diseases. Frontiers in Physiology. 2014;5:244.

58. Hlavaty T, Krajcovicova A, Koller T, et al.: Higher vitamin D serum concentration increases health related quality of life in patients with inflammatory bowel diseases. World Journal of Gastroenterology: WJG. 2014;20(42):15787-15796.

59. Ferguson LR: Nutritional Modulation of Gene Expression: Might This be of Benefit to Individuals with Crohn's Disease? Frontiers in Immunology. 2015; 6:467.

60. Moura FA, de Andrade KQ, Dos Santos JC, et al.: Antioxidant therapy for treatment of inflammatory bowel disease: Does it work? Redox Biology. 2015 23; 6:617-639.

61. Bouzid D, Gargouri B, Mansour RB, et al.: Oxidative Stress Markers in Intestinal Mucosa of Tunisian Inflammatory Bowel Disease Patients. Saudi Journal of Gastroenterology: Official Journal of the Saudi Gastroenterology Association. 2013;19(3):131-135.

62. Hokari R, Matsunaga H, Miura S: Effect of dietary fat on intestinal inflammatory diseases. Journal of Gastroenterology and Hepatology. 2013;28(4):33-6.

63. Zhang R, Gilbert S, Yao X, et al.: Natural compound methyl protodioscin protects against intestinal inflammation through modulation of intestinal immune responses. Pharmacology Research \& Perspectives. 2015;3(2): e00118.

64. Gil H-W, Lee E-Y, Lee J-H, et al.: Dioscorea batatas Extract Attenuates High-Fat DietInduced Obesity in Mice by Decreasing Expression of Inflammatory Cytokines. Medical 
Science Monitor: International Medical Journal of Experimental and Clinical Research. 2015; 21:489-495.

65. Carroll KC, Bartlett JG: Biology of Clostridium difficile: Implications for Epidemiology and Diagnosis. Annual Review of Microbiology. 2011; 65:501-21.

66. Shen A: A Gut Odyssey: The Impact of the Microbiota on Clostridium difficile Spore Formation and Germination. PLOS Pathogens. 2015;11(10):e1005157.

67. Petersen C, Round JL: Defining dysbiosis and its influence on host immunity and disease. Cellular Microbiology. 2014;16(7):1024-1033.

68. Cojocariu C, Stanciu C, Stoica O, et al.: Clostridium difficile infection and inflammatory bowel disease. The Turkish Journal of Gastroenterology. 2014;25(6):603-10.

69. Borody TJ, Paramsothy S, Agrawal G: Fecal Microbiota Transplantation: Indications, Methods, Evidence, and Future Directions. Current Gastroenterology Reports. 2013;15(8):337.

70. Saadatdoust Z, Pandurangan AK, Sadagopan SKA, et al.: Dietary cocoa inhibits colitis associated cancer: a crucial involvement of the IL-6/STAT3 pathway. The Journal of Nutritional Biochemistry. 2015; S0955-2863(15)00191-6.

71. Biasi F, Deiana M, Guina T, Gamba P, Leonarduzzi G, Poli G: Wine consumption and intestinal redox homeostasis. Redox Biology. 2014;2:795-802.

72. Patel MA, Patel PK, Patel MB: Effects of ethanol extract of Ficus bengalensis(bark) on inflammatory bowel disease. Indian Journal of Pharmacology. 2010;42(4):214-218.

73. Kruis W, Schutz E, Fric P, Fixa B, Judmaier G, Stolte M: Double-blind comparison of an oral Escherichia coli preparation and mesalazine in maintaining remission of ulcerative colitis. Aliment Pharmacol Ther 1997, 11:853-858.

74. Langmead L, Feakins RM, Goldthorpe S, Holt H, Tsironi E, De Silva A, Jewell DP, et al.: Randomized, double-blind, placebo-controlled trial of oral aloe vera gel for active ulcerative colitis. Alimentary Pharmacology and Therapeutics 2004, 19:739-747.

75. Hanai H, Iida T, Takeuchi K, Watanabe F, Maruyama Y, Andoh A, Tsujikawa T, et al.: Curcumin maintenance therapy for ulcerative colitis: randomized, multicenter, double-blind, placebo-controlled trial. Clin Gastroenterol Hepatol 2006, 4:1502-1506.

76. Kanauchi O, Mitsuyama K, Homma T, Takahama K, Fujiyama Y, Andoh A, Araki Y, et al.: Treatment of ulcerative colitis patients by long-term administration of germinated barley foodstuff: multicenter open trial. Int J Mol Med 2003, 12:701-704.

77. Kazi HA, Qian Z: Crocetin reduces tnbs-induced experimental colitis in mice by downregulation of nfkb. Saudi J Gastroenterol 2009, 15:181-187.

78. Yang L, Weaver V, Smith JP, Bingaman S, Hartman TJ, Cantorna MT: Therapeutic effect of vitamin d supplementation in a pilot study of crohn's patients. Clin Transl Gastroenterol 2013, 4:e33.

79. Kaliora AC, Stathopoulou MG, Triantafillidis JK, Dedoussis GVZ, Andrikopoulos NK: Alterations in the function of circulating mononuclear cells derived from patients with crohn's disease treated with mastic. World J Gastroenterol 2007, 13:6031-6036. 
80. Omer B, Krebs S, Omer H, Noor TO: Steroid-sparing effect of wormwood (Artemisia absinthium) in crohn's disease: a double-blind placebo-controlled study. Phytomedicine 2007, 14:87-95.

81. Ren J, Wu X, Liao N, Wang G, Fan C, Liu S, Ren H, et al.: Prevention of postoperative recurrence of crohn's disease: tripterygium wilfordii polyglycoside versus mesalazine. J Int Med Res 2013, 41:176-187.

82. Holtmeier W, Zeuzem S, Prei J, Kruis W, Bohm S, Maaser C, Raedler A, et al.: Randomized, placebo-controlled, double-blind trial of boswellia serrata in maintaining remission of crohn's disease: good safety profile but lack of efficacy. Inflamm Bowel Dis 2010, 17:573582.

83. Kelly CR, Kunde SS, Khoruts A: A How to Guide: Investigational New Drug Application for Fecal Microbiota Transplantation. Clinical gastroenterology and hepatology: the official clinical practice journal of the American Gastroenterological Association. 2014;12(2):283-288.

84. Wei Y, Zhu W, Gong J, et al.: Fecal Microbiota Transplantation Improves the Quality of Life in Patients with Inflammatory Bowel Disease. Gastroenterology Research and Practice. 2015:517597.

85. Laniro G, Bibbo S, Scaldaferri F, et al.: Fecal Microbiota Transplantation in Inflammatory Bowel Disease: Beyond the Excitement. Medicine (Baltimore). 2014; 93(19): e97.

86. Conway T, Cohen PS. Commensal and Pathogenic Escherichia coli. Metabolism in the Gut. Microbiology spectrum. 2015;3(3).

87. Haller D, Antoine JM, Bengmark S, et al.: Guidance for substantiating the evidence for beneficial effects of probiotics: probiotics in chronic inflammatory bowel disease and the functional disorder irritable bowel syndrome. Redox Biology. 2010;140(3):690S-7S.

88. Westendorf AM, Gunzer F, Deppenmeier S, et al.: Intestinal immunity of Escherichia coli NISSLE 1917: a safe carrier for therapeutic molecules. FEMS Immunology \& Medical Microbiology. 2005;43(3):373-84.

89. Wang Z-K, Yang Y-S, Chen Y, Yuan J, Sun G, Peng L-H.: Intestinal microbiota pathogenesis and fecal microbiota transplantation for inflammatory bowel disease. World Journal of Gastroenterology: WJG. 2014;20(40):14805-14820.

90. Miquel S, Leclerc M, Martin R, et al.: Identification of Metabolic Signatures Linked to AntiInflammatory Effects of Faecalibacterium prausnitzii. mBio. 2015;6(2):e00300-15.

91. Thorkildsen LT, Nwosu FC, Avershina E, et al.: Dominant Fecal Microbiota in Newly Diagnosed Untreated Inflammatory Bowel Disease Patients.Gastroenterology Research and Practice. 2013:636785.

92. De Mattos BRR, Garcia MPG, Nogueira JB, et al.: Inflammatory Bowel Disease: An Overview of Immune Mechanisms and Biological Treatments. Mediators of Inflammation. 2015:493012.

93. Barreiro-de-Acosta M, Lorenzo A, Dominguez-Munos JE: Efficacy of adalimumab for the treatment of extraintestinal manifestations of Crohn's disease. Revista Espanola de Enfermedades Digestivas. 2012; 104(9): 468-472. 
94. Horton HA, Dezfoli S, Berel D, et al.: Antibiotics for Treatment of Clostridium Difficile Infection in Hospitalized Patients with Inflammatory Bowel Disease.Antimicrobial Agents and Chemotherapy. 2014;58(9):5054-5059.

95. Zaura E, Brandt BW, Teixeria de Mattos MJ, et al.: Same Exposure but Two Radically Different Responses to Antibiotics: Resilience of the Salivary Microbiome versus LongTerm Microbial Shifts in Feces. The American Society for Microbiology. 2015;6(6): e0169315.

96. Versluis D, D’Andrea MM, Ramiro Garcia J, et al.: Mining microbial metatranscriptomes for expression of antibiotic resistance genes under natural conditions. Scientific Reports. $2015 ; 5: 11981$.

97. Lal S, Steinhart AH: Antibiotic therapy for Crohn's disease: A review. Canadian Journal of Gastroenterology. 2006;20(10):651-655.

98. Sutherland L, Singleton J, Sessions J, et al.: Double blind, placebo controlled trial of metronidazole in Crohn's disease. Gut. 1991;32(9):1071-1075.

99. Ursing B, Kamme G: Metronidazole for Crohn's disease. Lancet 1975; i:775-777.

100.Ursing B, Alm T, Barany F, et al.: A comparative study of metronidazole and sulfasalazine for active Crohn's disease: the cooperative Crohn's disease study in Sweden. II. Result. Gastroenterology 1982; 83:550-562.

101.Sandborn WJ, Feagan BG, Marano C, et al.: Subcutaneous Golimumab Induces Clinical Response and Remission in Patients With Moderate-to-Severe Ulcerative Colitis, Gastroenterology, 2014;146 (1):85-95.

102. Gómez-Gómez GJ, Masedo A, Yela C, et al.: Current stage in inflammatory bowel disease: What is next? World Journal of Gastroenterology. 2015; 21(40): 11282-11303.

103. Ghosh S, Goldin E, Gordon FH, et al.: Natalizumab for Active Crohn's Disease. The New England Journal of Medicine. 2003;2;348(1):24-32.

104.Feagan BG, Rutgeerts P, Sands BE, et al.: Vedolizumab as Induction and Maintenance Therapy for Ulcerative Colitis. The New England Journal of Medicine. 2013 Aug 22;369(8):699-710.

105. Amiot A, Peyrin-Biroulet L: Current, new and future biological agents on the horizon for the treatment of inflammatory bowel diseases. Therapeutic Advances in Gastroenterology. 2015;8(2):66-82.

106. Rinaudo-Gaujous M, Paul S, Tedesco ED, et al.: Review article: biosimilars are the next generation of drugs for liver and gastrointestinal diseases Alimentary Pharmacology \& Therapeutics. 2013 Oct;38(8):914-24

107.Zollman C, Vickers A: What is complementary medicine? BMJ: British Medical Journal. 1999;319(7211):693-696.

108. Triantafyllidi A, Xanthos T, Papalois A, Triantafillidis JK: Herbal and plant therapy in patients with inflammatory bowel disease. Annals of Gastroenterology: Quarterly Publication of the Hellenic Society of Gastroenterology. 2015;28(2):210-220. 
109. Wang X, Luo R, She B, Chen Y, Guo J: Traditional Chinese medicine (Shun-Qi-Tong-Xie Granule) for irritable bowel syndrome: study protocol for a randomised controlled trial. Trials. 2014;15:273.

110. Sałaga M, Zatorski H, Sobczak M, Chen C, Fichna J: Chinese Herbal Medicines in the Treatment of IBD and Colorectal Cancer: A Review. Current Treatment Options in Oncology. 2014;15(3):405-420.

111. Maragkoudaki M, Vaiopoulou A, Theodoropoulos GE, et al.: Specific detection of OCT4 isoforms in inflammatory bowel disease. Gut Pathogens. 2015; 7:25.

112. Actis GC, Pellicano R, Rosina F: Inflammatory bowel disease: Traditional knowledge holds the seeds for the future. World Journal of Gastrointestinal Pharmacology and Therapeutics. 2015;6(2):10-16.

113. Forte D, Ciciarello M, Valerii MC, et al.: Human cord blood-derived platelet lysate enhances the therapeutic activity of adipose-derived mesenchymal stromal cells isolated from Crohn's disease patients in a mouse model of colitis.Stem Cell Research \& Therapy. 2015;6(1):170.

114. Chen Q-Q, Yan L, Wang C-Z, et al.: Mesenchymal stem cells alleviate TNBS-induced colitis by modulating inflammatory and autoimmune responses. World Journal of Gastroenterology: WJG. 2013;19(29):4702-4717.

115. Karim BO, Rhee K-J, Liu G, Yun K, Brant SR: Proml Function in Development, Intestinal Inflammation, and Intestinal Tumorigenesis. Frontiers in Oncology. 2014; 4:323.

116. Sun T, Gao G-Z, Li R-F, et al.: Bone marrow-derived mesenchymal stem cell transplantation ameliorates oxidative stress and restores intestinal mucosal permeability in chemically induced colitis in mice. American Journal of Translational Research. 2015;7(5):891-901.

117.Haller D., Antoine J.-M., Bengmark S., Enck P., Rijkers G.T., Lenoir-Wijnkoop I: Guidance for substantiating the evidence for beneficial effects of probiotics: probiotics in chronic inflammatory bowel disease and the functional disorder irritable bowel syndrome. J. Nutr. 2010; 140:690S-697SS.

118. Seidner D.L., Lashner B.A: An oral supplement enriched with fish oil, soluble fiber, and antioxidants for corticosteroid sparing in ulcerative colitis: a randomized, controlled trial. Clin. Gastroenterol. Hepatol. 2005;3(4):358-369.

119.ParkM. -Y., Kwon H.-J., Sung M.-K: Dietary aloin, aloesin, or aloe-gel exerts antiinflammatory activity in a rat colitis model. Life Sci. 2011;88(11-12):486-492.

120.Hanai H., Sugimoto K: Curcumin has bright prospects for the treatment of inflammatory bowel disease. Curr. Pharm. Des. 2009;15(18):2087-2094.

121. Mill J, Lawrance IC: Preventing infective complications in inflammatory bowel disease. World Journal of Gastroenterology: WJG. 2014;20(29):9691-9698.

122. Babickova J, Gardlik R: Pathological and therapeutic interactions between bacteriophages, microbes and the host in inflammatory bowel disease. World Journal of Gastroenterology. 2015; 21(40): 11321-11330.

123. Cioffi M, Rosa AD, Serao R, Picone I, Vietri MT: Laboratory markers in ulcerative colitis: Current insights and future advances. World Journal of Gastrointestinal Pathophysiology. 2015;6(1):13-22. 